\title{
PROTEÇÃO DO PERfNEO DA PARTURIENTE E PROTEÇÃO DO FETO DURANTE O PERfODO EXPULSIVO DO PARTO
}

\author{
Maria Esperança de Marchiori Pedroso* \\ Toríbia Mottos*
}

PEDROSO, M. E. de M. \& MOTTOS, T. Proteção do períneo da parturiente e proteção do feto durante o período expulsivo do parto. Rev. Esc. Enf. USP, São Paulo, 14(1): 59-62, 1980.

Os autores descrevem uma técnica visando a proteção do períneo durante o desprendimento do polo cefálico e das espáduas do feto.

\section{INTRODUÇÃO}

Observamos, durante nosso período de experiência de alguns anos como docentes de enfermagem obstétrica, a incidência relativamente grande de roturas e lacerações do perineo e prolongamento de episiotomia, por falta do emprego de técnica adequada durante o desprendimento do polo cefálico e das espáduas.

A bibliografia referente à técnica de proteção do períneo durante o parto é muito escassa. Alguns autores como BRIQUET ${ }^{6}$, PSYCHYREMBEL ${ }^{9}$ e REZENDE ${ }^{10}$, citam a técnica de proteção do períneo no desprendimento do polo cefálico; porém, nada encontramos sobre a proteção do períneo no desprendimento do cinto escapular, quando, às vezes, ocorrem acidentes.

Em virtude da importância dada à profilaxia das complicações maternas e fetais,que podem ocorrer durante o período expulsivo, é que nos propusemos a elaborar este trabalho. Assim, o estudante poderá tomar os necessários cuidados, a fim de prevenir e detectar tais acidentes.

\section{SINTESE DA BACIA MOLE}

Para termos uma noção exata do que vamos proteger, necessário se faz uma síntese da bacia mole, também chamada infundíbulo perineovulvar, que é o plano de saída da bacia. Esta compreende duas formações: o diafragma pélvico e o urogenital.

O diafragma pélvico é constituído pelas fibras dos músculos elevadores do ânus $e$, posteriormente, pelos isquiococcígeos. Esse conjunto de fibras musculares dá passagem, na parte anterior, em uma linha mediana, ao reto, à vagina e à uretra.

$\mathrm{O}$ diafragma urogenital situa-se abaixo do anterior, sendo formado pelos músculos isquiocavernoso, bulbocavernosos, transversos superficiais e esfincter externo do ânus.

Durante o desprendimento da apresentação fetal ocorre a distenção passiva de todas as fibras musculares, o que permite a sua integração no canal de parto.

\footnotetext{
* Professor Assistente das disciplinas Enfermagem Obstétrica e Neonatal e Enfermagem Ginecológica da EEUSP.
} 


\section{COMPLICAÇŌES MATERNAS E FETAIS DURANTE 0 PERfODO EXPULSIVO}

As complicações maternas e fetais que ocorrem com maior freqüência são citadas por autores como GREENHILL ${ }^{7}$, GRELLE ${ }^{8}$ e REZENDE ${ }^{10}$.

No que diz respeito à parturiente, podemos citar, como complicação mais freqüente, o comprometimento das estruturas responsáveis pela sustentação do aparelho genital feminino. Isso ocorre, em geral, pelas contrapressões prolongadas executadas sobre o períneo e conseqüentemente sobre o polo fetal que se apresenta, na tentativa de se evitar roturas aparentes do assoalho pélvico. Poderá haver, posteriormente, um relaxamento das estruturas musculares do assoalho pélvico e, conseqüentemente, prolapso da bexiga, uretra, útero e vagina.

Poderá ocorrer, também, incontinência fecal, resultante de uma rotura perineal que se prolongou pelo ânus, atingindo o reto.

As lacerações recentes da região vulvoperineal são consideradas como porta de entrada para a invasão bacteriana, podendo causar infeç̧ões maternas.

Quanto ao feto, a complicação mais freqüente e mais grave é a lesão cranioencefálica, de intensidade variável, produzida pela descompressão brusca do polo cefálico, ou pela contrapressão excessiva exercida sobre o períneo, na tentativa de se evitar roturas das partes moles.

A fim de se evitar essas complicações, recomenda-se o uso da epsiotomia profilática, sempre que se fizer necessário, e proteção adequada no desprendimento do polo cefálico e do cinto escapular.

\section{TÉCNICA PARA A PROTEÇÃO DO PERINEO (com ou sem epsiotomia)}

\section{Proteção do períneo durante o desprendimento do polo cefálico}

Nas apresentações de vértice, durante o desprenidimento do polo cefálico, para evitar que se rompa o períneo ou que haja prolongamento da epsiotomia, é necessária assistência adequada, dada pelo profissional que assiste a parturiente.

0 momento oportuno de se proteger o períneo em multípara é quando este começa a se distender e, em primípara, quando o occipício solicita, deifnitivamente, a região vulvar.

Devemos salientar a importância da epsiotomia em primíparas bem como nas multíparas anteriormente epsiorrafisadas.

Nesse período, devemos orientar a parturiente sobre a força que precisa fazer com a finalidade de promover a liberação lenta e progressiva do polo cefálico. Ao mesmo tempo mantém-se a flexão da cabeça fetal, promovendo-se em seguida deflexão gradativa, para evitar o desprendimento brusco da apresentação.

A fim de se obter bom êxito durante a fase expulsiva, a parturiente deverá ter sido orientada sobre as vantagens da sua colaboração na mesma.

No desprendimento do polo cefálico é necessário haver ação coordenada das mãos do profissional que assiste a parturiente: 
- a mão esquerda será colocada na região vestibular, com os dedos polegar e indicador entreabertos sobre o suboccipicio fetal, para controlar a saída do crânio, enquanto não se completar a flexão, o que se faz através da locação do suboccipício na borda inferior da sínfese pública;

- a mão direita, ao mesmo tempo, deverá ser colocada, espalmada, na região vulvoperineal, com os dedos polegar e indicador junto à fúrcula, para reter a saída da região fronto-facial até que se libere o sincipúcio.

A ação conjunta das mãos tem duas finalidades: completar a flexão cefálica e proporcionar desprendimento lento e progressivo da apresentação fetal.

Após o desprendimento do polo cefálico executa-se a rotação externa da cabeça, com a finalidade de colocarmos o ponto de reparo fetal de volta à sua origem primitiva, ou seja, esquerda ou direita.

\section{Proteção do perineo durante o desprendimento das espáduas}

No decorrer do desprendimento das espáduas pode haver roturas do períneo que se manteve íntegro durante o desprendimento do polo cefálico.

Para que se processe corretamente o desprendimento das espáduas, devemos completar a rotação externa do polo cefálico, com a finalidade de colocar o biacromial no diâmetro ântero-posterior do estreito inferior da bacia óssea materna.

Com as mãos espalmadas e os dedos indicador e médio em fúrcula, apreende-se a cabeça através do biparietal e, por leve tração, executa-se um movimento de abaixamento, locando-se a inserção braquial do deltóide na borda inferior da sínfise púbica (hipomóclio).

A locação incorreta da inserção braquial do deltöide pode levar à fratura do úmero. A tração deverá ser exercida apenas na direção do eixo fetal, evitando-se trações exageradas e trações laterais que provocam o estiramento do plexo braquial, o que pode causar paresia ou paralisia braquial.

Após a locação do hipomóclio, a mão que se encontra no parietal superior é colocada espalmada na região vulvoperineal, com os dedos polegar e indicador junto à fúrcula, visando a proteção do períneo.

A mão que se encontra no parietal posterior executa um movimento de elevação para desprender o acrômio posterior.

A seguir, a mão que se encontra protegendo o períneo, volta à sua posição anterior e, por novo movimento de abaixamento, completa-se o desprendimento das espáduas. córmico.

Desprende-se, por fim, com movimentos de lateralidade, o restante do ovóide

PEDROSO, M. R. de M. \& MOTTOS, T. The protection of the perineoum of the patient during the delivery of the head and shoulders of the fetus. Rev. Esc. Enf. USP, São Paulo, 14(1):59-62, 1980.

The authors describe a technique of perineoum protection during the delivery of the fetus head and shoulders. 


\section{REFERENCIAS BIBLIOGRAFICAS}

1. ANDERSON, B. G. Obstetrícla para la enfermera. Buenos Aires, Troquiel, 1970.146 p.

2. BARBOSA, L. A. H. Obstetrícia prática. 5. ed. Rio de Janeiro, Científica, 1961. 694 p.

3. BENSON, R. C. Manual de obstetrícia e ginecologia. Rio de Janeiro, Guanabara Koogan, 1970. $861 \mathrm{p}$.

4. BETHEA, D. C. Enfermería maternoinfantll. 2. ed. Mexico, Interamericana, 1977. 252 p.

5. BOOKIMILLER, M. N. Enfermeria Obstétrica. 5. ed. Mexico, Interamericana, 1967. 547 p.

6. BRIQUET, R. C. Obstetrícia normal. 3. ed. Săo Paulo, Guia Fiscal, 1956.538 p.

7. GREENHILL, J. P. Obstetrícia. Rio de Janeiro, Interamericana, 1974. 831 p.

8. GRELLE, F .C. Manual de obstetricis. 2. ed. Rio de Janeiro, Atheneu, 1960. $699 \mathrm{p}$.

9. PSCHYREMBEL, W. Obstetrícla práctica. 3. ed. Barcelona, Labor, 1978. 414 p.

10. REZENDE, J. de Obstetrícia. 3. ed. Rio de Janeiro, Guanabara Koogan, 1974.1125 p. 